\title{
Summary of Environmental Impact Assessment for Mining Seafloor Massive Sulfides in Japan
}

\author{
Teruyoshi Narita ${ }^{1}$, Junya Oshika ${ }^{1}$, Nobuyuki Okamoto ${ }^{1}$, Tetsuhiko Toyohara ${ }^{1,2}$ and Tetsuya Miwa ${ }^{3}$ \\ 1. Japan Oil, Gas and Metals National Corporation, Minato-ku, Tokyo 105-0001, Japan \\ 2. (Present address) Marine Biological Research Institute of Japan Co., Ltd, 4-3-16 Yutaka-cho, Shinagawa-ku, Tokyo 142-0042, \\ Japan \\ 3. Japan Agency for Marine-Earth Science and Technology, Kanagawa Prefecture 237-006, Japan
}

\begin{abstract}
JOGMEC (Japan Oil, Gas and Metals National Corporation) has conducted exploration and research in Japan's EEZ (exclusive economic zone) from fiscal year 2008, under contract by the METI (Ministry of Economy, Trade and Industry), for the commercialization of SMS (Seafloor Massive Sulfide). As there is currently no commercial mining precedent of SMS, it is necessary to consider the potential impacts of mining on the surrounding environment, and to promote long term sustainable projects. In particular, due to the existence of specific chemosynthetic ecosystems and unique biological communities around the SMS area, both quantitative evaluations of potential environmental impacts and consequent environmental conservation strategies, are necessary in order to avoid and or minimize the potential detrimental effects to the ecosystem, as much as possible. The environmental research programs consist of baseline surveys, environmental impact modeling, and methodological concepts which will be applied to conserve biodiversity. In this paper, we will primarily provide an overview of the project conducted by JOGMEC during 2008-2012.
\end{abstract}

Key words: Seafloor Massive Sulfide, environmental baseline survey, environmental impact and prediction model, conservation measures of biodiversity.

\section{Introduction}

SMS (Seafloor Massive Sulfide) deposits are of high interest as future commercial mining venture options as they contain high concentrates of base metals such as copper, zinc, lead, and precious metals such as platinum, gold, silver $[1,2]$. It is also well known that specific chemosynthetic ecosystems and unique biological communities exist in areas surrounding SMS deposits. The "chemosynthetic ecosystem" refers to an ecosystem consisting of organisms which use hydrogen sulfide or methane produced by hydrothermal vent microorganisms as their energy source [3]. It is expected that such biological communities belonging to this ecosystem not only possess a high academic value, but also present as potentially useful genetic resources in the

Corresponding author: Teruyoshi Narita, Ph.D., research fields: marine ecology. Email: narita-teruyoshi@jogmec.go.jp. pharmaceutical and chemical industries. As a result, the conservation of biological diversity has attracted much attention in recent years. Quantitative predictions and evaluations of the impacts of SMS mining on the surrounding environment, as well as the introduction of measures to conserve biodiversity are essential to avoid and or minimize the potential detrimental effects on the ecosystem.

The concern for the environmental impact caused by development of seabed resources has been studied in practice. As an example, Nautilus Minerals Inc. (hereinafter, Nautilus Inc.) headquartered in Canada, is continuing to promote the development of SMS deposits in the Bismarck Sea in PNG (Papua New Guinea) (Solwara1 project), and submitted an EIA (environmental impact assessment) report to the PNG government in 2008 [4]. Furthermore, the ISA (International Seabed Authority), which was established under the United Nations Convention on 
the Law of the Sea as the highest institution, is able to make the final approval of seabed resources development in the high seas. Recommended under "Exploration Rules" [5], upon exploration of polymetallic sulphide, contractors are to carry out EIA (environmental impact assessments) and implement environmental monitoring surveys in order to avoid and minimize, where possible, any environmental impact caused by development activities. In July 2013, the ISA also introduced guidelines for environmental research of seabed resource exploration under the "recommendation for the guidance of the contractors for the assessment of the possible environmental impacts arising from exploration for marine minerals in the area" [6] (hereinafter, "Environmental Guideline"). In recent years, many papers associated with environmental risks, the conservation of biological communities, and the need for environmental impact assessments on SMS mining have been published [7-9]. As a result, the necessity of implementing an EIA when developing SMS deposits has become common global knowledge.

Based on the R \& D program consisting of resource evaluation, environmental impact study, mining system technology and processing technology fields aimed at the commercialization of SMS deposits within 10 years (Stage 1: 2008-2012; Stage 2: 2013-2017), JOGMEC conducted research in Japan's EEZ (the Okinawa trough and Izu-Bonin Arc) from fiscal year 2008 under contract by the METI, and the final evaluation report of Stage 1 of the SMS project was issued in fiscal year 2012 [10]. The EIA consists of the environmental baseline survey in order to establish the natural situation of target sea areas, the development of an environment numerical model to predict the impact on the surrounding environment caused by mining activities and the measures for conservation of biodiversity by genetic analysis of hydrothermal vent organisms. Toyohara and Okamoto [11] and Toyohara et al. [12] have already introduced the outline and overall concepts of the EIA of the
SMS mining by JOGMEC. In this paper, we will provide a review of the results for the 2008-2012 project and discuss the prospects for the second stage of SMS mining.

\section{Materials and Methods}

\subsection{The Concept of EIA in this Project}

The basic mining design of this project consists of a SMT (seafloor mining tool) for digging and collecting ore, a riser pipe for raising mined ore to the MSV (mining support vessel) as a slurry, and an MSV for transporting the recovered ore to a shuttle barge for transporting it to land for processing and smelting. Given this mining system, the major potential impacts (Fig. 1) are as follows:

(1)directly destruction of the deep-sea habitat due to SMT activities;

(2)suspended solids and re-sedimentation due to plume formation in the bottom layer;

(3)diffusion of discharged water (including suspended solids and toxic metals) in the bottom sea layer after ore is dewatered on the MSV;

(4)noise and light of SMT and/or MSV.

The implication of (1) is potential direct mortality of benthic fauna. The implication of (2) is the potential for indirect mortality of benthic fauna living in surrounding waters resulting from being buried during the re-sedimentation of suspended solids. The implication of (3) is possible effects on the biological

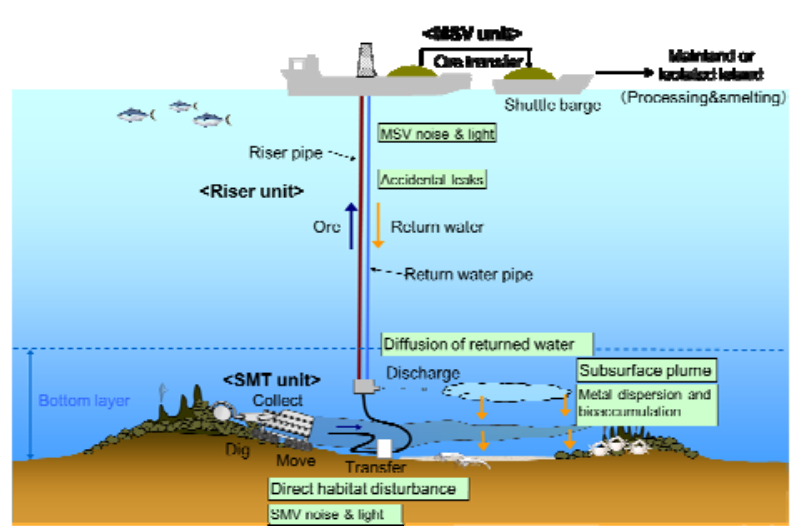

Fig. 1 Potential impacts of SMS mining. (Referred to Toyohara et al. (2011) and slightly revised). 
communities, including commercial fish populations in the surface and mid-water layers, by changing the composition of phytoplankton, which are responsible for the primary production, via diffusion of turbidity. The implication of (4) is potential influence on the behaviors of the marine mammals including whales and dolphins due to noise and the spill of light during SMT and MSV activities. Moreover, as the suspended solids generated by SMT activities may contain toxic elements, such as arsine and mercury, there is also a risk that fauna could ingest high levels of these elements and organisms of higher trophic levels could then, upon consumption, accumulate the toxicants in their own bodies.

When conducting an EIA, it is necessary to consider the impact of SMS mining on the target sea area, by first utilizing an environmental baseline survey in order to understand the biological, physical and chemical environmental characteristics of the target area.

\subsection{Environmental Baseline Survey}

A preliminary baseline survey was conducted in both the Okinawa Trough and Izu-Bonin Arc spanning five years, from 2008 to 2012 (Fig. 2).

In Stage 1 of the project during 2008-2012, 20 research cruises were conducted to identify environmental characteristics, such as the benthic communities, which may be seriously affected by SMS mining activities, water quality, and sediment characteristics by using JOGMEC's R/V Hakurei-maru No.2 etc.

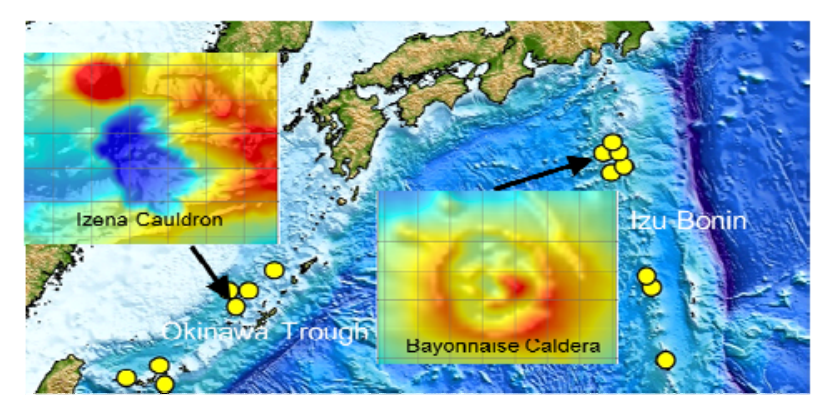

Fig. 2 The locations of survey site. (Referred to Toyohara et al. (2011) and slightly revised)
Water temperature, salinity and water depth were measured by using the CTD (conductivity, temperature, and depth sensor) at inside and outside of Cauldron. To measure the spatial and seasonal characteristics of water currents and velocity, ADCP (Acoustic Doppler Current Profiler) mooring systems were placed for ca. 1 year at inside and outside of Cauldron. Water currents and velocity were measured in six to ten layers from surface to bottom. Especially, they were also measured ten layers every $1 \mathrm{~m}$ near sea-bed below ADCP inside Cauldron. To know the distribution of the megafauna (more than $3 \mathrm{~cm}$ full length), the observation of sea-bed were conducted by using a hi-definition video camera at seven transects inside Cauldron and two transects outside Cauldron, respectively. The water sampling was conducted by using a multi-bottle sampler at inside and outside of Cauldron. For chemical analysis, water sampling was conducted in 16 layers from surface to bottom. For measuring Chl. $a$ and collecting pico- $(0.2-2 \mu \mathrm{m})$, nano-zooplanktons $(2-20 \mu \mathrm{m})$ and small zooplankton $(>20 \mu \mathrm{m})$, water sampling were conducted in nine layers every $25 \mathrm{~m}$ from surface to $200 \mathrm{~m}$ depth and in 14 layers every $25 \mathrm{~m}$ from surface to $1,500 \mathrm{~m}$ depth, respectively. Samples collected by multi-bottle samplers were fixed by $2 \%$ formalin neutral buffer solution, and conducted morphological identification by using microscopy. To measure the sedimentation rate for ca. 1 year, sediment traps were also placed at $40 \mathrm{~m}$ above the seafloor both inside and outside Cauldron, respectively. Mass flux, organic particle flux, lithogenic particle flux, carbonate flux, opal flux and metals etc. were analyzed. To know the vertical distributions of large zooplankton in water column, sampling was conducted by using ORI net at each four layers such as 0-200, 200-500, 500-1,000, and 1,000-10 $\mathrm{m}$ above bottom. Also, to know the distributions of plankton near the sea-bottom, sampling of near the sea-bed fauna was conducted by using the sled net (mesh size: $330 \mu \mathrm{m}$ ). The sled net was towed ca. $100 \mathrm{~m}$ at daytime, and covered ca. 
$1,500 \mathrm{~m}^{2}$. To clarify the sediment properties and distribution patterns of the benthos (bacteria $(<1 \mu \mathrm{m})$, nanobenthos $(1-32 \mu \mathrm{m})$, meiobenthos $(32-500 \mu \mathrm{m})$, and macrobenthos $(>500 \mu \mathrm{m}))$, sampling by using the MC (multiple corer) was conducted at inside and outside of Cauldron. Core samples from surface to 5 $\mathrm{cm}$ layer were cut into 5 layers such as surface-0.5, $0.5-1,1-2,2-3$ and $3-5 \mathrm{~cm}$, respectively. Benthic organisms samples $(>32 \mu \mathrm{m})$ collected by MC were fixed by $10 \%$ formalin neutral buffer solution contained rose bengal, and conducted morphological identification by using microscopy. The identification kept lower taxonomic resolution. Bacteria and nanobenthos were counted cell abundance under fluorescence microscopy. Pore water samples were collected by syringe from side of MC core and nutrients and metals and methane were analyzed. The CTD, ADCP, water sampling and MC survey were conducted at max. five stations inside Cauldron and three stations outside Cauldron, respectively. Regional surveys near the SMS site were conducted using a ROV (remotely operational vehicle) fitted with a hi-definition video camera, suction sampler and RO (rosette) sampler. Suction sampler was used to collecting megafauna for gene analysis. A list of environmental items collected in the survey is shown in Table 1. Most of the environmental items collected in this project cover the recommend items in

Table 1 The status of the SMS baseline study conducted from 2008 to 2012 fiscal years.

$\square$ : ISA recommendation; $O$ : Done; $X$ : None; $\triangle$ : Shortage (1 time or 2 times data); -: None Unit.

\begin{tabular}{|c|c|c|c|}
\hline Category & Survey Items & Unit & Status \\
\hline \multirow{8}{*}{\begin{tabular}{|l|} 
Censor \\
measurement
\end{tabular}} & Temperature & $\operatorname{deg} \mathrm{C}$ & 0 \\
\hline & Salinity & PSU & 0 \\
\hline & Density $(\sigma t)$ & $\mathrm{kg} / \mathrm{m}^{3}$ & O \\
\hline & Light intensity & $\mathrm{mg} / \mathrm{m}^{3}$ & 0 \\
\hline & Vertical distribution of light & $\mu \mathrm{g} / \mathrm{L}$ & $\triangle$ \\
\hline & Dissolved oxygen & $\mathrm{ml} / \mathrm{L}$ & 0 \\
\hline & Turbidity & NTU, FTU & 0 \\
\hline & Noise & $\mathrm{dB}$ & $\triangle$ \\
\hline Mooring system & Current/Velocity & $\mathrm{m} / \mathrm{s}$ & 0 \\
\hline \multirow{2}{*}{ Video } & Scavenger & inds. & $\triangle$ \\
\hline & Collection points of megabenthos & - & 0 \\
\hline \multirow{22}{*}{\begin{tabular}{|l|}
$\begin{array}{l}\text { Water } \\
\text { sampling }\end{array}$ \\
\end{tabular}} & $\mathrm{pH}$ & - & $\mathrm{O}$ \\
\hline & Alkalinity & $\mu \mathrm{mo} / \mathrm{kg}$ & 0 \\
\hline & Dissolved oxygen (DO) & $\mathrm{ml} / \mathrm{L}$ & 0 \\
\hline & Oxygen minimum zone & - & $x$ \\
\hline & Suspended solid (SS) & $\mathrm{mg} / \mathrm{L}$ & 0 \\
\hline & $\mathrm{PO}_{4}-\mathrm{P}$ & $\mu \mathrm{mol} / \mathrm{L}$ & 0 \\
\hline & $\mathrm{SiO}_{2}-\mathrm{Si}$ & $\mu \mathrm{mol} / \mathrm{L}$ & 0 \\
\hline & $\mathrm{NH}_{4}-\mathrm{N}$ & $\mu \mathrm{mol} / \mathrm{L}$ & 0 \\
\hline & $\mathrm{NO}_{3}-\mathrm{N}$ & $\mu \mathrm{mol} / \mathrm{L}$ & 0 \\
\hline & $\mathrm{NO}_{2}-\mathrm{N}$ & $\mu \mathrm{mol} / \mathrm{L}$ & 0 \\
\hline & TOC & - & 0 \\
\hline & POC & $\mu \mathrm{g} / \mathrm{L}$ & O \\
\hline & PON & $\mu \mathrm{g} / \mathrm{L}$ & 0 \\
\hline & $\mathrm{H}_{2} \mathrm{~S}$ & $\mathrm{mg} / \mathrm{L}$ & 0 \\
\hline & Thermal vent water Metals, $\mathrm{CH}_{4}$ ) & $\mathrm{mg} / \mathrm{L}$ & 0 \\
\hline & Trace Metals & $\mathrm{mg} / \mathrm{L}$ & 0 \\
\hline & Chl-a & $\mu \mathrm{g} / \mathrm{L}$ & O \\
\hline & Pheophytin & $\mu \mathrm{g} / \mathrm{L}$ & O \\
\hline & Zooplankton & inds. $/ \mathrm{m}^{3}$ & 0 \\
\hline & Phytoplankton & cells/L & 0 \\
\hline & Pico-/nano-plankton & cells or inds./L & 0 \\
\hline & Bacteria & cells/L & O \\
\hline \multirow[t]{8}{*}{ Sediment trap } & Particle flux & $\mathrm{mg} / \mathrm{m}^{2} / \mathrm{g}$ & O \\
\hline & $\mathrm{TOC} \cdot \mathrm{T}-\mathrm{N}$ & $\%$ & O \\
\hline & Opal & $\%$ & 0 \\
\hline & Inorganic carbonate & $\%$ & 0 \\
\hline & Aluminosilicate & $\%$ & O \\
\hline & Sulfide & $\mathrm{mg} / \mathrm{g}$ & 0 \\
\hline & Trace metals & $\mathrm{mg} / \mathrm{kg}$ & 0 \\
\hline & Stable isotope & $\%$ & 0 \\
\hline \multirow[t]{4}{*}{ Organisms } & Morphorogical/Genetic information & - & $\mathrm{O}$ \\
\hline & Trace metals & $\mu \mathrm{g} / \mathrm{g}$-wet & $\triangle$ \\
\hline & Ecotoxicology & - & $x$ \\
\hline & Stable isotope & $\%$ & 0 \\
\hline
\end{tabular}

\begin{tabular}{|c|c|c|c|c|}
\hline \multicolumn{2}{|c|}{ Category } & Survey Items & Unit & Status \\
\hline Trap sampling & Benthos & Scavenger & inds. & $\triangle$ \\
\hline \multirow{3}{*}{\begin{tabular}{|l|} 
Net \\
sampling
\end{tabular}} & \multirow{3}{*}{$\begin{array}{l}\text { Plankton/ } \\
\text { Benthos }\end{array}$} & Macrozooplankton & inds. $/ \mathrm{m}^{3}$ & $\triangle$ \\
\hline & & Megafauna & inds. & $\Delta$ \\
\hline & & Near-bottom fauna & inds. $/ \mathrm{m}^{3}$ & $\Delta$ \\
\hline \multirow{20}{*}{$\begin{array}{l}\text { Sediment } \\
\text { sampling }\end{array}$} & \multirow[t]{17}{*}{ Sediment } & Grain size & - & 0 \\
\hline & & Density & $\mathrm{g} / \mathrm{cm}^{3}$ & 0 \\
\hline & & Specific gravity & - & $x$ \\
\hline & & Shear strength & - & $x$ \\
\hline & & Water content & wt \% & 0 \\
\hline & & IL & wt $\%$ & 0 \\
\hline & & Total organic carbon TOC) & - & 0 \\
\hline & & Total carbon TC) & wt \% & 0 \\
\hline & & Organic carbon OC) & wt \% & 0 \\
\hline & & Inorganic carbon (IC) & wt $\%$ & 0 \\
\hline & & Total Nitrogen (TN) & wt $\%$ & 0 \\
\hline & & $\mathrm{Pb}-210$ & - & $x$ \\
\hline & & Trace metals & $\mathrm{mg} / \mathrm{kg}$ & 0 \\
\hline & & Sulfide & $\mathrm{mg} / \mathrm{g}$ & 0 \\
\hline & & Stable isotope & $\%$ & 0 \\
\hline & & Sediment depth & $\mathrm{cm}$ & $x$ \\
\hline & & Settling velocity & - & $\times$ \\
\hline & \multirow[t]{3}{*}{ Benthos } & Macrofauna & inds. $/ 100 \mathrm{~cm}^{2}$ or $10 \mathrm{~cm}^{2}$ & 0 \\
\hline & & Meiofauna & inds. $/ 10 \mathrm{~cm}^{2}$ or $\mathrm{g}(\mathrm{DW})$ & 0 \\
\hline & & Microfauna & cells/g & 0 \\
\hline \multirow{14}{*}{\multicolumn{2}{|c|}{ Pore water }} & $\mathrm{pH}$ & - & $\Delta$ \\
\hline & & Alkalinity & $\mu \mathrm{mo} / \mathrm{kg}$ & $\Delta$ \\
\hline & & $\mathrm{CH}_{4}$ & $\mathrm{mg} / \mathrm{L}$ & $\Delta$ \\
\hline & & $\mathrm{H}_{2} \mathrm{~S}$ & $\mathrm{mg} / \mathrm{L}$ & $\Delta$ \\
\hline & & Carbon dioxide & $\mu \mathrm{mol} / \mathrm{kg}$ & $\Delta$ \\
\hline & & Dissolved oxygen (DO) & $\mathrm{m} / \mathrm{L}$ & $\triangle$ \\
\hline & & $\mathrm{PO}_{4}-\mathrm{P}$ & $\mu \mathrm{mol} / \mathrm{L}$ & $\Delta$ \\
\hline & & $\mathrm{SiO}_{2}-\mathrm{Si}$ & $\mu \mathrm{mo} / \mathrm{L}$ & $\Delta$ \\
\hline & & $\mathrm{NH}_{4}-\mathrm{N}$ & $\mu \mathrm{mo} / \mathrm{L}$ & $\Delta$ \\
\hline & & $\mathrm{NO}_{3}-\mathrm{N}$ & $\mu \mathrm{mo} / \mathrm{L}$ & $\Delta$ \\
\hline & & $\mathrm{NO}_{2}-\mathrm{N}$ & $\mu \mathrm{mol} / \mathrm{L}$ & $\Delta$ \\
\hline & & Total organic carbon (TOC) & - & $x$ \\
\hline & & Metals & $\mathrm{mg} / \mathrm{L}$ & $\Delta$ \\
\hline & & ORP & - & $x$ \\
\hline \multirow{6}{*}{$\begin{array}{l}\text { Other } \\
\text { informations }\end{array}$} & \multirow{2}{*}{\begin{tabular}{|l|}
$\begin{array}{l}\text { Thermal vent } \\
\text { species }\end{array}$ \\
\end{tabular}} & Growth/Recruitment rete,Trophic status & - & $\Delta$ \\
\hline & & Habitat mapping & - & 0 \\
\hline & \multirow[t]{2}{*}{ Necton } & Fishery & - & $\Delta$ \\
\hline & & Kills/Large concentration & - & $\times$ \\
\hline & Sea birds & Kills/Large concentration & - & $x$ \\
\hline & Topology & GIS & - & 0 \\
\hline
\end{tabular}


Table 2 The category and survey items of preliminary EIA for small scale SMS test mining in 2012. (Each survey item was selected by referring to Japanese domestic laws including the "Environmental Impact Assessment Act”).

\begin{tabular}{|c|c|c|c|c|c|}
\hline \multicolumn{4}{|c|}{ Environmental Issue } & \multirow{2}{*}{\begin{tabular}{|c|} 
Selection \\
-
\end{tabular}} & Reason \\
\hline \multirow{12}{*}{$\begin{array}{l}\text { Keeping natural } \\
\text { elements ecologically- } \\
\text { friendly }\end{array}$} & Atmosphere & Atmosphere & $\begin{array}{l}\text { Air quality, Noise, } \\
\text { Vibration, Odor }\end{array}$ & & There is no emission of gas and no subjects caused by the harmful effects of noise, vibration and odor. \\
\hline & \multirow{8}{*}{$\begin{array}{l}\text { Aquatic } \\
\text { environment }\end{array}$} & \multirow{6}{*}{ Water } & Temperature & - & $\begin{array}{l}\text { The changes in water temperature may be considered by releasing the excess water warmed in the raising ore } \\
\text { unit but it is not selected since the raiser test is not carried out. }\end{array}$ \\
\hline & & & Turbidity & O & The occurrence of turbidity may be considered by SMV test minning. \\
\hline & & & Toxic metal & O & The diffusion of toxic metals contained in the seidiments may be considered by the SMV test minning. \\
\hline & & & Dissolved oxygen & - & $\begin{array}{l}\text { The changes in dissolved oxygen contents may be considered by releasing the excess water increased the } \\
\text { dissolved oxygen content in the raising ore unit but it is not selected since the raiser test is not carried out. }\end{array}$ \\
\hline & & & $\begin{array}{l}\text { Organic matter } \\
\text { Nutrinet }\end{array}$ & - & $\begin{array}{l}\text { The changes in organic matter and nutrinet contents may be considered by releasing the excess water containing } \\
\text { high concentration nutrients of deep-sea origin by the operation of the raising ore unit but it is not selected } \\
\text { since the raiser test is not carried out. }\end{array}$ \\
\hline & & & $\mathrm{CO}_{2} / \mathrm{CH}_{4}$ & $\triangle$ & $\begin{array}{l}\text { The gushing out the methane in the sediment and } \mathrm{CO}_{2} \text { stored in liquid and hydrate state by } \mathrm{SMV} \text { test minning } \\
\text { and ranging into the atmosphere of them may be considered, but these are difficult to predict if the distribution } \\
\text { and amount of them are known. }\end{array}$ \\
\hline & & \multirow{2}{*}{ Sediment } & $\begin{array}{l}\text { Organic matter } \\
\text { Nutrinet }\end{array}$ & O & $\begin{array}{l}\text { The changes in layer structure by diffusion and resedimentation of suspension and the contents of organic } \\
\text { matter and nutrinet in sediment may be considered by SMV test minning. }\end{array}$ \\
\hline & & & Toxic metal & O & $\begin{array}{l}\text { The expansion of distribution of toxic metals following to the diffusion and resedimentation of suspension } \\
\text { may be considered. }\end{array}$ \\
\hline & \multicolumn{3}{|l|}{ Ground water } & - & There is not considered to impact on groundwater. \\
\hline & Others & Noise & Water noise & O & $\begin{array}{l}\text { The changes in behavior of such as Nekton may be considered by the water noise generated during moving, } \\
\text { digging and collecting of SMV. }\end{array}$ \\
\hline & \multicolumn{2}{|c|}{ Geology and Orhers } & Topography & O & The geological changes may be considered by SMV test mining. \\
\hline \multirow[t]{7}{*}{\begin{tabular}{l|} 
Systematic maintenance \\
of biodiversity
\end{tabular}} & Phyton & Phytoplankton & Primary production & - & $\begin{array}{l}\text { The changes in water quality by the occurrence of the turbidity may be considered to be affected phytoplankton } \\
\text { community, but it is not selected since the raiser test is not carried out. }\end{array}$ \\
\hline & \multirow{5}{*}{ Animals } & Zooplankton & Biomass & O & The changes in biomass of near-bottom zooplankton may be considered due to the occurrence of turbidity. \\
\hline & & \multirow[b]{2}{*}{ Nekton } & Biomass & O & The changes in biomass of near-bottom nekton may be considered due to the occurrence of turbidity. \\
\hline & & & Toxic metal & $\triangle$ & $\begin{array}{l}\text { The accumulation of toxic metals and growth inhibition to nekton with the diffusion of toxic metals by the test } \\
\text { mining may be considered, but they are not selected since the prediction of the accumulation in the body of } \\
\text { organisms to toxic metals is difficult. }\end{array}$ \\
\hline & & \multirow{2}{*}{ Benthos } & Biomass & O & $\begin{array}{l}\text { The directly (buried or death) or indirectly (change in food environment) imapct on benthos may be considered } \\
\text { by SMV test mining. }\end{array}$ \\
\hline & & & $\begin{array}{l}\text { Toxic metal } \\
\text { contents }\end{array}$ & $\triangle$ & Same reason as Nekton \\
\hline & \multicolumn{2}{|l|}{ Ecosystem } & $\begin{array}{l}\text { Hydrothermal vent } \\
\text { ecosystem }\end{array}$ & O & There is considered to impact on hydrothermal vent ecosystem. \\
\hline \multirow[t]{2}{*}{$\begin{array}{l}\text { Relations between nature } \\
\text { and human being }\end{array}$} & \multicolumn{3}{|l|}{ Landscape } & - & There is not considered to impact on the landscape since the structures do not establish at sea. \\
\hline & \multicolumn{3}{|c|}{ Site of relations between nature and human being } & - & The survey site is not applicable. \\
\hline \multirow[t]{2}{*}{$\begin{array}{l}\text { Environmental load of a } \\
\text { contaminant }\end{array}$} & \multicolumn{3}{|l|}{ Seawage } & - & There is no discharge of seawage. \\
\hline & \multicolumn{3}{|c|}{ Green house gas } & - & Greenhouse gas emissions is small and short-term period during test mining. \\
\hline
\end{tabular}

O: Select; $\triangle$ : There are no technics to evaluate; -: Not select.

the "Environmental Guidelines" set by the ISA [6].

\subsection{The Development of the Environmental Prediction} Model and Preliminary EIA

The need for implementation of a baseline survey before commencing mining activities, and predicting and assessing the potential environmental impacts that result are outlined in the ISA's "Environmental Guideline" [6]. The environmental prediction model constructs both three-dimensional water currents model to predict the advection and diffusion of physicochemical factors and ecosystem models for the surface, middle and bottom sea layers. For high accuracy prediction, it is important to both demonstrate the actual currents and ecosystems of each layer by models, and to predict as close to actual mining conditions as possible.

The environmental impact prediction model 
developed to date, as shown in Fig. 1, includes (1)the dispersion and re-sedimentation model of suspended solids resultant from SMT activities, such as digging and moving, (2)The dispersion model of discharged water, and (3)The impact and recovery prediction model of the ecosystem [13] for more information about the design concept of each model). Each model was constructed using virtually set mining conditions and organism biomasses, and when tested for validity, all models were assessed to be functional.

In 2012, prior to carrying out test mining with a small test tool developed by JOGMEC at Izena Cauldron, the preliminary EIA was conducted using the developed models. Although the seabed excavation work is not regulated by the "Environmental Impact Assessment Act" [14] of Japan at present, the selection of environmental items for the preliminary EIA was decided based firstly on consideration of this law (Table 2). Impact simulations for the surrounding environment, caused by test mining, were conducted by using the dispersion and re-sedimentation model of suspended solids. The models were inputted with mining conditions such as test duration (7 hours/day in 8-day operation), the expected amount of suspended solid generation (emissions $0.2 \mathrm{~m}^{3} /$ day, particle size of $0.075 \mathrm{~mm}$ or less) and the about $3 \mathrm{~cm} / \mathrm{s}$ current speed at the seabed.

Each model was constructed using virtually set mining conditions and organism biomasses, and when tested for validity, all models were assessed to be functional.

\subsection{Environmental Conservation Measures}

The unique hydrothermal vent biological communities and associated habitats are expected to be destroyed by SMS mining [7, 15]. Therefore, measures to conserve biodiversity, aimed at the avoidance and reduction of adverse effects, are required for the commercialization mining of SMS. Many species of thermal vent organisms have a pelagic larvae stage in their life cycle and are able to be transported long-distances and safely dispersed in a new area [16]. However it is very difficult to directly evaluate the direction and amount of larval dispersal in each sea area, hence indirect estimation by genetic methods is generally performed [17]. Consequently, the genetic connections between different hydrothermal vents species have become known [17, 18]. In this project, we consider these characteristics of hydrothermal vent species and the concept of zonation, separating the protected (non-mining) and mining areas, in order to conserve the biodiversity of the target sea area. Essentially, the protected areas (un-mining) are determined following confirmation of the presence or absence of genetic connections between hydrothermal vent species commonly found in target mining areas and determination of the genetic source of intermittently formed populations in the greater surrounding area. In an attempt to facilitate the recovery of the biological communities in mining area following the conclusion of mining activities, the aforementioned pelagic larvae will be supplied to the mining area, sourced from the untouched protected areas (non-mining) (Fig. 3). When comparing the genetic diversity within species, the method of amplifying DNA (deoxyribonucleic acid) fragment sequences of the target organism by PCR (Polymerase Chain Reaction), to determine the homology of the

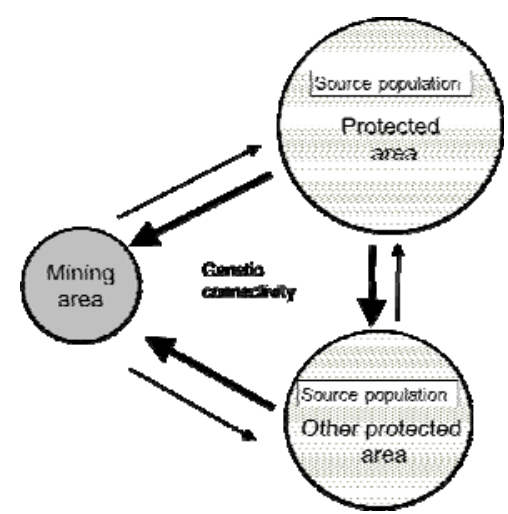

Fig. 3 Schematic diagram demonstrating larval supply of hydrothermal vent species population from protected area to mining area (refer to Toyohara et al. (2011), slightly revised). Arrow thickness represents the magnitude of larval supply from one area to another. 
sequence is widely utilized. Recently, it has been discovered that the nucleotide sequence information of the COI (cytochrome c oxidase I) region of the mitochondria can be used to detect and quantify the unique biodiversity due to the presence of highly generic primers in the COI mitochondrial DNA of marine invertebrates [19]. A haplotype is a group of genes within an organism that was inherited together from a single parent. There are differences in haplotype among populations resultant of mutation over years of generational changes. In this project, the homology of haplotypes of mitochondrial DNA in organisms was analyzed to compare the genetic diversity of hydrothermal vent species.

\section{Results and Discussion}

\subsection{Environmental Baseline Survey}

Summary of the results of the baseline survey in the Okinawa Trough and Izu-Bonin Arc are shown in Table 3 [20-22]. The characteristics of species composition of plankton and benthos, water quality, sediment, current direction/velocity and sedimentation were very different between the two areas. Of note, in the 200-250 $\mathrm{m}$ layer above the bottom in Izena Cauldron clearly higher levels of turbidity and abundance of bacteria and zooplankton (mainly Oikopleura sp.) were recorded. In the future study, it is important to detailly analyze the seasonal and interannual variations in these baseline items by comparing to other results of hydrothermal vent areas to know the characteristic of the Okinawa Trough and Izu-Bonin Arc. The environmental baseline survey of Stage 1 was carried out primarily around the hydrothermal vent near the bottom layer, but actual mining activities are assumed to be carried out at the point where hydrothermal activity has stopped, and hence there is a need to conduct a further survey of non-hydrothermal vent area. In addition, it is necessary to conduct an environmental survey of the surface and middle layers due to the potential for biological communities of those layers to be effected by the diffusion of turbidity, as outlined above.

\subsection{The Development of the Environmental Prediction Model and Preliminary EIA}

Judging from the results, the impact of turbidity is predicted to be highly localized, as locations where the value of turbidity was more than 100 times the natural value of the turbidity (average 0.045) was limited to the immediate area surrounding the release point (orange area) (Fig. 4). An environmental monitoring survey was consequently conducted in order to attempt to confirm the prediction results. However, the results could not be sufficiently confirmed

Table 3 Summary of the results of baseline survey conducted from fiscal years 2008 to 2012 in the Okinawa Trough and Izu-Bonin Arc.

\begin{tabular}{|c|c|c|}
\hline Category & Izena Cauldron & Bayonnaise Caldera \\
\hline Benthic Fauna & $\begin{array}{l}\text { Shinkaia crosneri and Alvinocaris spp. dominates in the active hydrothermal regions. } \\
\text { The genera Rossellidae and Caridea dominates in the inactive regions. }\end{array}$ & $\begin{array}{l}\text { Neoverruca sp. and Gandalfus yunohana dominates in the active hydrothermal regions. } \\
\text { The genera Primnoidae dominates in the inactive regions. }\end{array}$ \\
\hline Plankton & $\begin{array}{l}\text { Biomass of the both bacteria and zooplankton is higher in the bottom layer than the middle } \\
\text { layer. }\end{array}$ & $\begin{array}{l}\text { Biomass of the both phyto- and zoo-planktons is vertically and horizontally normal as the } \\
\text { open sea. }\end{array}$ \\
\hline Water quality & $\begin{array}{l}\text { The turbidity tended to be higher inside Cauldron }(0.001 \sim 0.725 \mathrm{FTU}) \text { than outside } \\
\text { Cauldron }(0.001 \sim 0.069 \mathrm{FTU}) \\
\text { Water temperatures of the end-member hydrothermal fluid are around } 200-300^{\circ} \mathrm{C}\end{array}$ & $\begin{array}{l}\text { The water quality is vertically and horizontally normal as the open sea. } \\
\text { Water temperatures of the end-member hydrothermal fluid was around } 100-150^{\circ} \mathrm{C}\end{array}$ \\
\hline Sediment & $\begin{array}{l}\text { Concentrations of } \mathrm{Hg} \text { (Max. } 8 \mathrm{mg} / \mathrm{kg} \text { ) and } \mathrm{As} \text { (Max. } 80 \mathrm{mg} / \mathrm{kg} \text { ) are widely high in the Cauldron } \\
\text { (see Ishida et al. (2011)). }\end{array}$ & $\begin{array}{l}\text { Concentrations of Hg (Max.ca. } 50 \mathrm{mg} / \mathrm{kg} \text { ) and As (Max. ca. } 1400 \mathrm{mg} / \mathrm{kg} \text { ) are high near the } \\
\text { hydrothermal vent in the Caldera (see Ishida et al. (2012)). }\end{array}$ \\
\hline Current & Bottom current is ordinarily low $(5 \sim 10 \mathrm{~cm})$ throughout a year. & $\begin{array}{l}\text { Bottom current is low }(5 \sim 10 \mathrm{~cm}) \text { but surface and middle current occasionally reaches }>60 \\
\mathrm{~cm} / \mathrm{s} \text {. }\end{array}$ \\
\hline Particle flux & $\begin{array}{l}\text { Mass flux is } 2-2.5 \text { times greater in the Cauldron than in the other North Pasific sea ( } 44 \mathrm{~N} \text {, } \\
155 \mathrm{E} \text { and } 37 \mathrm{~N}, 174 \mathrm{E} \text { ) (see Maeda et al. (2012)). }\end{array}$ & The seasonal varioation in mass flux shows high from December to April folowing year. \\
\hline Others & $\begin{array}{l}\text { Tuna and bonito moves around Izena Cauldron. The tuna long line fishery is conducted from } \\
\text { May to August. Fisheries of the deep-sea snappers are also common in Okinawa trough. }\end{array}$ & $\begin{array}{l}\text { The tuna long line fishery is conducted from Dec. to April. The main fields of the pelagic } \\
\text { fisheries distribute around the north Izu-bonin located in } 80 \mathrm{~km} \text { distant from Bayonnaise } \\
\text { caldera. }\end{array}$ \\
\hline
\end{tabular}




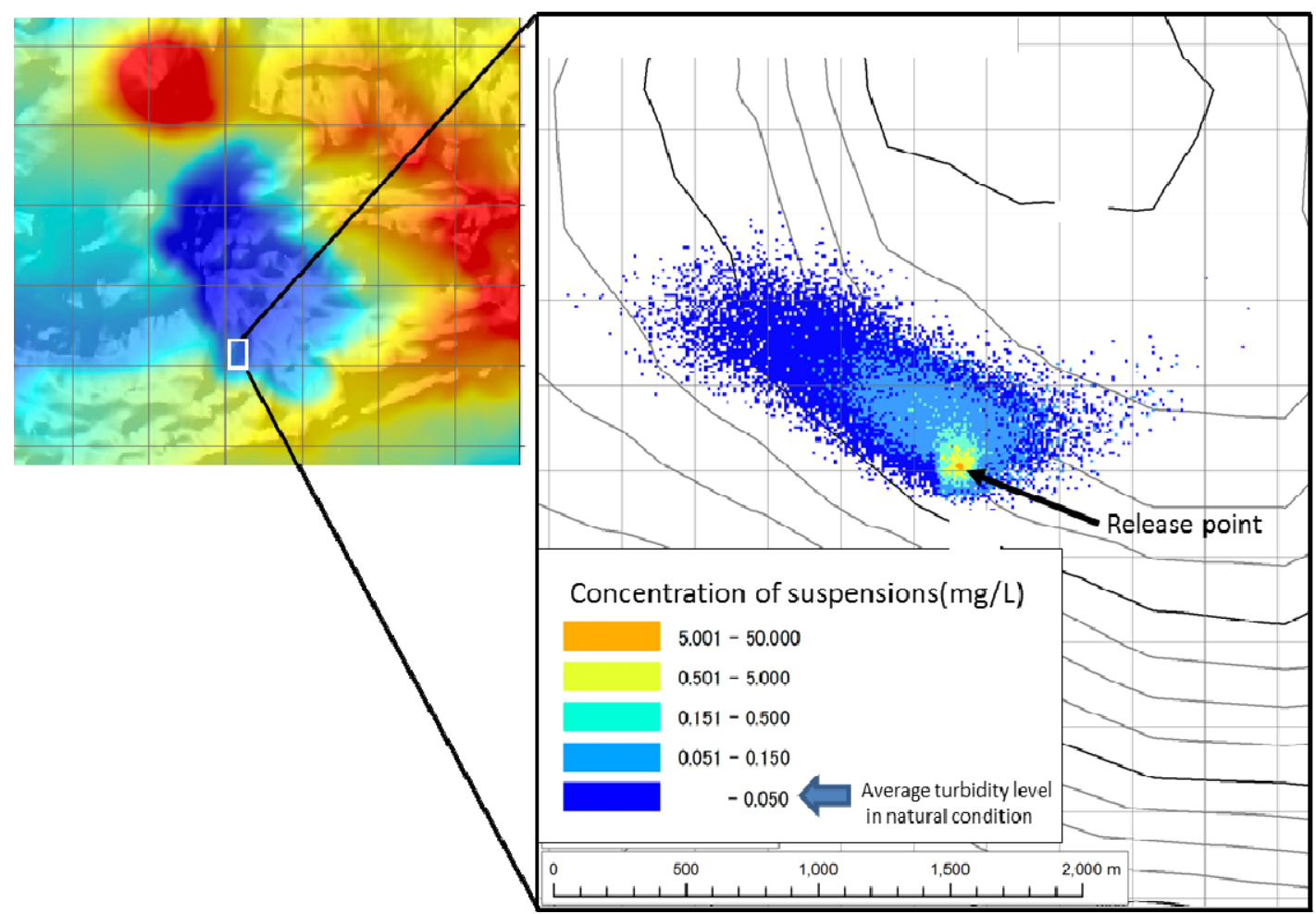

Fig. 4 Predicted dispersion of suspended solids by using the model prior to the mining test in 2012.

as the current direction based on the ocean circulation model and the analysis of ADCP in the environment baseline survey differed from the analysis of ADCP, placed just before the test mining. In addition, predictions were made on the assumption of continuous operation of 7 hours/day, but the actual operating time of the testing tool was only a very short 2.5 hours. The difference in current direction between the measured and predicted results has been deemed to be due to the micro-topography of the near seabed which had a significant effect on the current direction. Therefore, to raise the accuracy of the developed prediction model, it is necessary to replicate the current field, giving consideration to the micro-topography, and to input actual test conditions into the prediction model whilst reconfirming the validity of the prediction result.

\subsection{Environmental Conservation Measures}

As an example, the results of genetic analysis of the Lepetodrilus nux, the dominant hydrothermal vent species in Okinawa Trough, are outlined below. Genes were extracted from the same species from each area, with the results of comparison of the haplotypes presented in Fig. 5 as a network, illustrating the closeness of haplotypes among the same species across each different locality. The circles are patterns of haplotypes and the colors in circles indicate each locality. The number of circles represents the level of diversity of haplotypes and circle size represents the

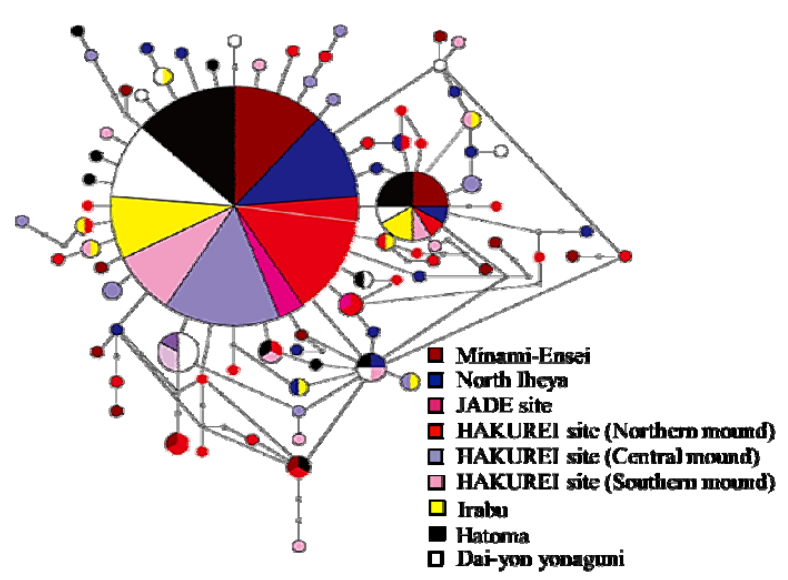

Fig. 5 Haplotype network of Lepetodrilus nux collected from the Okinawa Trough and surrounding waters, based on the sequence of the mitochondrial COI (cytochrome oxidase I gene). 
frequency of occurrence of the haplotype pattern. Where there were no genetic exchanges for long periods of time, the circle is shown in a single color which indicates that same haplotypes did not appear in common in each locality and hence becomes a completely separate form among each locality. Inferring from the results of Fig. 5, as the haplotype networks of this species consist predominantly of one dominant haplotype, it is estimated that there are genetic exchanges among each locality. Table 4 shows the degree of immigration and emigration of Lepetodrilus nux by estimating the effective population size and movement of individual organism numbers between each locality. The "effective population size" is the number of individual organisms within the overall population that were successful in breeding and creating offspring.

"Moving individuals" refers to the estimated value for the individual organisms which succeeded in moving between populations, however organisms that died for unknown reasons during movement between populations are not included [17]. Excluding the results from Southern Ensei, Hatoma and Irabu, wherein the collected number of individuals of this species were less than 20 , there is no bias in the degree of immigration and emigration of populations across Izena and the surrounding waters.

As represented by the formation of the CBD (Convention on Biological Diversity), awareness regarding the importance of conservation of biodiversity and environmental protection is increasing throughout the world, and some countries have already attempted to protect sea areas, including the hydrothermal vent ecosystems and communities, from development activities such as seabed mining through the implementation of MPA (marine protected areas), which are not available for mining.

For example, Canada, Portugal and Mexico respectively declared the hydrothermal vents of the northeast Atlantic Ocean, offshore of Vancouver, the Guaymas Basin, of the Eastern Pacific Ocean, and Azores, along the Mid-Atlantic Ridge, as MPAs [23]. In addition, the ISA is proposing a set of MPA networks in order to conserve biodiversity in the manganese nodules areas of the East Pacific Ocean [24]. The CBD has resolved to declare multiple MPAs together as a functional network in order to reduce the extinction risk facing MPAs (the biological communities

Table 4 The effective population size (gray area) and movement of individual numbers of Lepetodrilus nux collected from Okinawa Trough and surrounding waters (white area) (relative value in parentheses). The moving individual numbers among each locality are represented by the moving individual numbers from populations shown in bold characters to those shown in standard font.

\begin{tabular}{|c|c|c|c|c|c|c|}
\hline & North Iheya & $\begin{array}{c}\text { Izena } \\
\text { JADE site }\end{array}$ & $\begin{array}{c}\text { Izena } \\
\text { Hakurei site } \\
\text { Northern mound } \\
\end{array}$ & $\begin{array}{c}\text { Izena } \\
\text { Hakurei site } \\
\text { Central mound }\end{array}$ & \begin{tabular}{|c|} 
Izena \\
Hakurei site \\
Southern mound \\
\end{tabular} & $\begin{array}{c}\text { Dai-Yon } \\
\text { Yonaguni noll }\end{array}$ \\
\hline North Iheya & $\begin{array}{r}1450.81 \\
0.076)\end{array}$ & $\begin{array}{c}310.38 \\
0.016)\end{array}$ & $\begin{array}{l}745.44 \\
0.039)\end{array}$ & $\begin{array}{c}217.93 \\
0.011)\end{array}$ & $\begin{array}{c}338.07 \\
0.018)\end{array}$ & $\begin{array}{l}414.2 \\
0.022)\end{array}$ \\
\hline $\begin{array}{c}\text { Izena } \\
\text { JADE site }\end{array}$ & $\begin{array}{c}252.13 \\
0.013)\end{array}$ & $\begin{array}{l}732.4 \\
0.038)\end{array}$ & $\begin{array}{c}398.95 \\
0.021)\end{array}$ & $\begin{array}{c}340.17 \\
0.018)\end{array}$ & $\begin{array}{r}442.44 \\
0.023)\end{array}$ & $\begin{array}{c}156.82 \\
0.008)\end{array}$ \\
\hline $\begin{array}{c}\text { Izena } \\
\text { Hakurei site } \\
\text { Northern mound }\end{array}$ & $\begin{array}{c}512.41 \\
0.027)\end{array}$ & $\begin{array}{c}635.54 \\
0.033)\end{array}$ & $\begin{array}{r}187.29 \\
0.01)\end{array}$ & $\begin{array}{c}485.84 \\
0.025)\end{array}$ & $\begin{array}{c}437.01 \\
0.023)\end{array}$ & $\begin{array}{c}412 \\
0.022)\end{array}$ \\
\hline $\begin{array}{c}\text { Izena } \\
\text { Hakurei site } \\
\text { Central mound } \\
\end{array}$ & $\begin{array}{r}295.89 \\
0.015)\end{array}$ & $\begin{array}{c}504.57 \\
0.026)\end{array}$ & $\begin{array}{l}779.66 \\
0.041)\end{array}$ & $\begin{array}{r}577.16 \\
0.03)\end{array}$ & $\begin{array}{c}317.19 \\
0.017)\end{array}$ & $\begin{array}{r}334.77 \\
0.018)\end{array}$ \\
\hline $\begin{array}{c}\text { Izena } \\
\text { Hakurei site } \\
\text { Southern mound } \\
\end{array}$ & $\begin{array}{c}696.49 \\
0.036)\end{array}$ & $\begin{array}{c}442.16 \\
0.023)\end{array}$ & $\begin{array}{c}534.72 \\
0.028)\end{array}$ & $\begin{array}{l}784.77 \\
0.041)\end{array}$ & $\begin{array}{l}805.63 \\
0.042)\end{array}$ & $\begin{array}{l}795.15 \\
0.042)\end{array}$ \\
\hline $\begin{array}{c}\text { Dai-Yon } \\
\text { Yonaguni noll }\end{array}$ & $\begin{array}{c}479.99 \\
0.025)\end{array}$ & $\begin{array}{c}239.29 \\
0.013)\end{array}$ & $\begin{array}{r}482.99 \\
0.025)\end{array}$ & $\begin{array}{r}1049.61 \\
0.055)\end{array}$ & $\begin{array}{c}546.63 \\
0.029)\end{array}$ & $\begin{array}{c}981.22 \\
0.051)\end{array}$ \\
\hline
\end{tabular}


in each MPA must have ecological or genetic connectivity). It is considered that complying with the standards and procedures that are resolved by the CBD and the setting of the MPA network is a necessary step in order to achieve both successful development of deep-sea mineral resources and the conservation of biological diversity [25].

Utilization of this method fulfills the recommendation to "assess regional distribution of species and genetic connectivity of key species", contained within the ISA's "Environmental Guideline" [6], and therefore, this method of evaluation of genetic connectivity by using population genetics is positioned to become a standard method of biodiversity conservation. A similar approach, based on this concept, has been utilized by Nautilus Inc. [4] at their Solwaral project, but while Nautilus Inc. focused on the genetic connectivity between the mining target sea area and the adjacent sea area, our project targeted the spread sea areas over several hundred $\mathrm{km}$ of the Izu-Ogasawara region and Okinawa Trough.

In Stage 1 of the project, (2008-2012), 17 species of dominant hydrothermal vent organisms, which are commonly found in the Okinawa Trough and Izu-Bonin Arc including Sagami Bay (Honshuu), were examined for the presence or absence of genetic connections via application of the above method of analysis utilizing the nucleotide sequence of mitochondrial DNA. So far, the genetically endemic species has not been confirmed in each sea area, though the 17 species of dominant hydrothermal vent organisms, found in the sea areas surrounding Okinawa Trough and Izu-Bonin Arc, including the species shown in Fig. 6, displayed observable genetic connections. In addition, it was confirmed that neither the Okinawa Trough nor the Izu-Bonin Arc is the genetic source of populations of 15 (Mollusca: 6 species; Polychaeta: 3 species; Crustacea: 6 species) of the more than 20 species' individuals captured for population analysis. This fact suggests that the

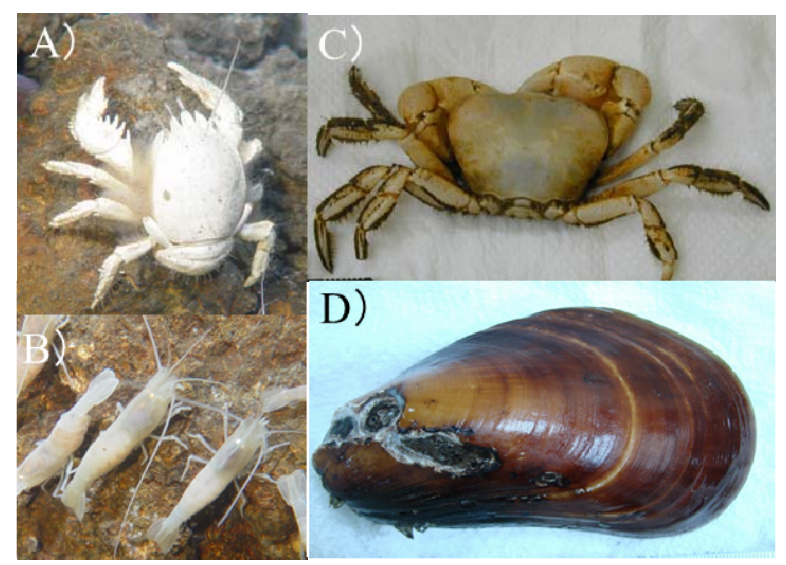

Fig. 6 Example of target hydrothermal vent species for genetic analysis. (A: Shinkaia crosnieri (Galatheid Crab); B: Alvinocaris longirostris (Shrimp); C: Gandalfus yunohana (Crab); D: Bathymodiolus platifrons (Mussel)

conservation of hydrothermal vent species may be possible by setting the protect area.

The survey of the bottom region performed in the Stage 1 project (2008-2012) was carried out near hydrothermal vent zones, but actual mining activities are assumed to be carried out in the non-hydrothermal sites. Therefore, in the Stage 2 project (2013-2017), it is necessary to perform genetic analysis of non-hydrothermal vent species to confirm the genetic connection of species between the areas and help with developing comprehensive conservation measures.

\section{Conclusions}

We have obtained the basic biological and physic-chemical environmental information necessary for an EIA of both the Okinawa Trough and Izu-Bonin Arc through surveys conducted in the area between fiscal years 2008 and 2012. Most of the environmental items collected in this project cover the recommended items contained in the ISA's environmental guidelines, and this inter-annual survey spans a longer period than any other seabed environmental survey in the world to date. The preliminary EIA, using the developed environmental prediction model, was also conducted prior to test mining on an actual SMS site in 2012 in the final year of Stage 1. It was confirmed through the test mining that the impact of turbidity is very 
localized and an environmental monitoring survey was conducted in order to confirm this prediction result. The prediction model will be further improved through consideration of both current velocity/direction, measured by mooring systems, and the micro topography of the seabed. In regards to the examination of environmental conservation measures, it was confirmed that both the Okinawa Trough and Izu-Bonin Arc are not the genetic source of dominant hydrothermal vent species populations found in the areas. Assuming the implementation of an EIA associated with the riser test in Stage 2, it will be necessary to accumulate baseline data for the surface and middle layers whilst working towards further development of EIA methods to coincide with the development of SMS deposits.

\section{Acknowledgements}

This project was supported by the METI (Ministry of Economy, Trade and Industry). The authors would like to express appreciation to everyone concerned with this program.

\section{References}

[1] Herzig, P. M. 1999. "Economic Potential of Sea-Floor Massive Sulphide Deposits: Ancient and Modern. Philosophical Transactions of the Royal Society Mathematical." Physical \& Engineering Sciences (357): $861-75$.

[2] Baker, M. C., and German, C. R. 2009. "Going for Gold! Who will Win in the Race to Exploit Ores from the Deep Sea?" Ocean Challenge (16): 10-7.

[3] Grassle, J. F. 1980. "Hydrothermal Vent Animals: Distribution and Biology." Science (229): 713-7.

[4] Nautilus Minerals Nuigini Limited. 2008. "Environmental Impact Statement Solwara 1 Project." Main Report Coffy Natural Systems, Brisbane.

[5] International Seabed Authority. 2013. "Regulation on Prospecting and Exploration for Polymetallic Sulphides in the Area." Accessed at October 1st, 2014. http://www.isa.org.jm/files/documents/EN/19Sess/Counci 1/ISBA-19C-CRP1.pdf.

[6] International Seabed Authority. 2013. "Recommendation for the Guidance of Contractors for the Assessment of the Possible Environmental Impacts Arising from Exploration for Marine Minerals in the Area." Accessed at October 1 st, 2014. http://www.isa.org.jm/files/documents/EN/19Sess/LTC/I SBA-19LTC-8.pdf.

[7] Van Dover, C. L. 2011. "Mining Seafloor Massive Sulphides and Biodiversity: What Is at Risk?" Journal of Marine Science (68): 341-8.

[8] Boschen, R. E., Rowden, A. A., Clark, M. R., and Gardner, J. P. A. 2013. "Mining of Deep-Sea Seafloor Massive Sulfides: A Review of the Deposits, Their Benthic Communities, Impacts from Mining, Regulatory Frameworks and Management Strategies." Ocean \& Coastal Management (84): 54-67.

[9] Collins, P. C., Croot, P., Carlsson, J., Colaco, A., Grehan, A., Hyeong, K., Kennedy, R., Mohn, C., Smith, S., Yamamoto, H., and Rowden, A. 2013. "A Primer for the Environmental Impact Assessment of Mining at Seafloor Massive Sulfide Deposits." Marine Policy (42): 198-209.

[10] The Ministry of Economy, Trade and Industry. 2013. Final Reports of Stage 1 Research and Development Program of Seafloor Massive Sulphide: 110 (in Japanese). Accessed at October 1st, 2014. http://www.meti.go.jp/press/2013/07/20130705003/2013 0705003-2.pdfAsearch='\%E6\%B5\%B7\%E5\%BA\% $\% 5 \% \mathrm{E}$ 7\%86\%B1\%Е6\%B0\%B4\%Е9\%89\%B1\%Е5\%BA\%8A\% Е9\%96\%8B $\%$ E7\%99\%BA\%Е $\% \% A 8 \% 88 \%$ E7\%94\%BB'.

[11] Toyohara, T., and Okamoto, N. 2011. "Approach to Environmental Impact Assessment and Conservation Measures of Biodiversity for Mining Seafloor Massive Sulfides." Presented at the 22nd Ocean Engineering Symposium Japan.

[12] Toyohara, T., Okamoto, N., Kawai, T., Kodama, T., and Shibasaki, H. 2011. "Environmental Research for Assessing the Impact of Mining." In Proceedings of the 30th International Conference on Ocean, Offshore and Arctic Engineering, No. OMAE2011-49906.

[13] Ichikawa, T., and Nakata, K., 2010. "Development of a Numerical Simulation Model for Environmental Impact Assessment of Seafloor Massive Sulfides Mining." Kaiyo to Seibutsu, Seibutsu Kenkyusya (32): 554-60 (in Japanese with English abstract).

[14] The Ministry of Environment. 1997. "Environmental Impact Assessment Act.” (in Japanese). http://law.e-gov.go.jp/htmldata/H09/H09HO081.html.

[15] Van Dover, C. L., Smith, C. R., Ardron, J., Dunn, D., Gjerde, K., Levin, L., and Smith, S. 2012. "The Dinard Workshop Contributors, Designating Networks of Chemosynthetic Ecosystem Reserves in the Deep Sea." Marine Policy (36): 378-81.

[16] Mullineaux, L. S., and France S. C. 1995. Dispersal Mechanisms of Deep-Sea Hydrothermal Vent Fauna. In Seafloor Hydrothermal Systems: Physical, Chemical, Biological, and Geological Interactions (Geophysical 
Monograph), eds. S. E. Humphris, R. A. Zierenberg, L. S. Mullineaux, R. E. Thomson.: 408-23.

[17] Watanabe, H., Kojima, S., and Fujikura, K. 2010 "Estimation of Population Dynamics of Deep-sea Hydrothermal Vent Animal Assemblages Using Genetic Analysis." Kaiyo to Seibutsu, Seibutsu Kenkyusya (32): 561-6 (in Japanese with English abstract).

[18] Kojima, S. 2002. “Deep-Sea Chemoautosynthesis-Based Communities in the Northwestern Pacific." Journal of Oceanography (58): 343-63.

[19] Folmer, O., Black, M., Hoeh, W., Lutz, R. R., and Vrijenhoek, R. 1994. "DNA Primer for Amplification of Mitochondrial Cytochrome C Oxidase Subunit I from Diverse Metazoan Invertebrates." Molecular Marine Biology and Biotechnology (3): 294-9.

[20] Ishida, H., Maeda, N., Miwa, T., Yamazaki, T., Shirayama, Y., Toyohara, T., Okamoto, N., and Kodama, T. 2011. "Characteristics of the Environment around a Massive Sea-Floor Sulfide Area in the Okinawa Trough." In Proceedings of the 30th International Conference on Ocean, Offshore and Arctic Engineering, No. OMAE2011-49987.

[21] Ishida, H., Onishi, Y., Miwa, T., Yamazaki, T., Shirayama, Y., Okamoto, N., and Kodama, T. 2012. "Environmental Baseline Survey for Mining of the Sea-Floor Massive Sulfide (SMS) Areas around Japanese
Islands." In Proceedings of the 31th International Conference on Ocean, Offshore and Arctic Engineering, No. OMAE2012-83323.

[22] Maeda, N., Ishida, H., Yamanaka, T., Miwa, T., Yamazaki, T., Shirayama, Y., Okamoto, N., and Kodama, T. 2012. "Dynamics of the Settling and Suspended Particles around a Sea-Floor Massive Sulfide in Japan." In Proceedings of the 31th International Conference on Ocean, Offshore and Arctic Engineering, No. OMAE2012-83322.

[23] International Seabed Authority 2011. "ISA TECHNICAL STUDY SERIES-Environmental Management of Deep-Sea Chemosynthetic Ecosystems Justification of and Considerations for a Spatially-Based Approach (9): 80.

[24] International Seabed Authority. 2011. "Environmental Management Plan for the Clarion-Clipperton Zone (2011)." Accessed at October 1st, 2014. http://www.isa.org.jm/files/documents/EN/17Sess/LTC/I SBA-17LTC-7.pdf.

[25] Shirayama, Y. 2013. "The development of Seafloor Mineral Resources and Marine Environmental Conservation." In Seafloor Mineral Resources for Industrial Use-New Mineral Resources in Japanese Exclusive Economic Zone- ed. K.Iizasa, Chapter 10: 164-72 (in Japanese). 